\title{
Interview
}

\section{De grote toezichtinterviewestafette - deel 3:}

\section{Autoriteit Consument en Markt}

\author{
Marije Batting en Martijn Groenleer*
}

Voor deze aflevering van het estafette-interview spraken Marije Batting en Martijn Groenleer namens de redactie van Tijdschrift voor Toezicht met Martijn Snoep, sinds 1 september 2018 bestuursvoorzitter van de ACM. ${ }^{1}$

Mede naar aanleiding van de suggesties van Hanzo van Beusekom, bestuurslid van de Autoriteit Financiële Markten (AFM), die we interviewden voor nummer 2019-3 van Tijdschrift voor Toezicht, spraken wij met Martijn over de elementen van een goede toezichtstrategie en over de balans tussen handhaven en beïnvloeden.

* Mr. M.L. Batting is advocaat-partner bestuursrecht bij Pels Rijcken \& Droogleever Fortuijn en redacteur van het Tijdschrift voor Toezicht. Prof. dr. M.L.P. Groenleer is hoogleraar Regionaal recht aan het Tilburg Institute of Governance (TIG) en redacteur van Tijdschrift voor Toezicht.

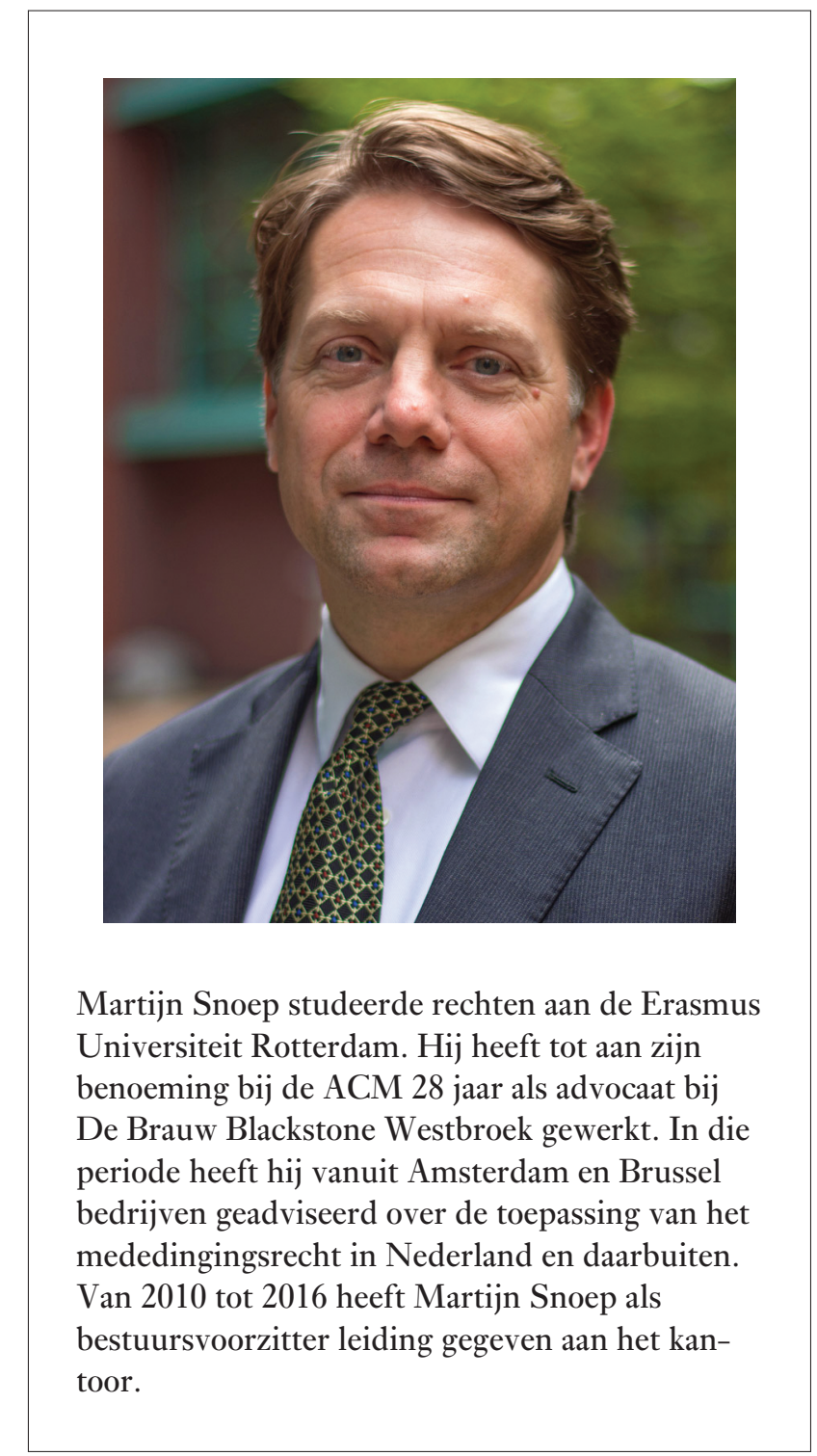

1. Het gesprek vond begin november 2019 plaats. 
Redactie: Wat zijn, volgens jou, de essentiële elementen van een goede toezichtstrategie?

Martijn Snoep: Er zijn drie belangrijke elementen. Het eerste is doelgerichtheid. Het toezicht moet het doel dat je als toezichthouder nastreeft dichterbij brengen, je moet daarmee verschil maken.

Het tweede is transparantie; je moet als toezichthouder met open vizier strijden. Zowel naar de ondertoezichtgestelde als naar de samenleving moeten wij als toezichthouder verantwoording afleggen, zeggen wat je gaat doen en waarom je het gedaan hebt.

Het derde is verbinding met de samenleving. Een onafhankelijke toezichthouder moet zijn onafhankelijkheid waarborgen, maar dat betekent niet onafhankelijkheid vanuit een ivoren toren.

Redactie: De vraag is dan vervolgens hoe je die elementen incorporeert in jullie eigen toezichtstrategie.

Martijn Snoep: Bij iedere interventie die wij doen, en dan bedoel ik interventie in de meest ruime zin van het woord, bedenken wij vooraf heel goed wat we hiermee willen bereiken. Wat is ons doel, in welke mate brengt de interventie ons dichterbij dat doel en wat is onze strategie om dat doel te bereiken? Daarna meten we of we dit hebben bereikt. De eerlijkheid gebiedt te zeggen dat we daar de ene keer net iets gedisciplineerder in zijn dan de andere keer, maar het is wel het streven om dit bij al onze interventies zo te doen.

Redactie: En hoe zorg je ervoor dat jullie vooraf ook echt nadenken over jullie doelen?

Martijn Snoep: Dat zit in een standaardwerkwijze die de basis vormt voor het opstarten van een project. We geven daarnaast veel interne voorlichting over hoe je aan effectmeting doet, hoe je een nulmeting kan doen en wat daar de verschillende methoden voor zijn. Het zit ook in diverse interne trainingen die wij hebben over het vaststellen van toezichtdoelen.

\section{Redactie: Wat zijn precies jullie toezichtdoelen?}

Martijn Snoep: Heel grof gezegd hebben we vier doelen: voorkomen, vergelden, voorlichten en vergoeden. Soms kun je meerdere doelen hebben, soms moet je kiezen en soms zijn het doelen die haaks op elkaar staan. Daar moet je tussen bewegen en eigenlijk zit daar nog iets onder, want waarom hebben wij deze vier doelen? Daarvoor moeten we terug naar de reden waarom wij zijn opgericht.

Je kunt schaarse goederen en middelen op twee manieren verdelen. De overheid kan zeggen, jij krijgt van mij dit tegen deze prijs en op dat moment, of je kunt het de markt laten bepalen. Voor welke van de twee modellen je kiest, is een politieke keuze. Daar waar het marktmechanisme een rol speelt bij de verdeling van schaarse goederen en middelen komen wij, als toezichthouder, kijken. Ons doel is ervoor te zorgen dat markten goed werken voor mensen en bedrijven. Dat zit op twee niveaus: op het eerste niveau waarborgt het mede- dingingsrecht dat het marktproces zelf blijft werken. Op het tweede niveau moet de wetgever corrigerend optreden waar het marktproces op zichzelf goed werkt, maar de uitkomst ongewenst is vanuit bepaalde andere publieke belangen dan marktwerking. In een aantal gevallen heeft de wetgever gezegd dat de ACM toezicht moet houden op dat correctiemechanisme, bijvoorbeeld op het gebied van consumentenbescherming.

De burger moet het vertrouwen hebben dat het marktproces werkt, dat de uitkomsten goed, eerlijk en aanvaardbaar zijn en dat er een overheid is die ingrijpt als het marktproces niet werkt of de uitkomst oneerlijk is. Om dat vertrouwen te voeden, hebben we een toezichtstrategie die is gebaseerd op 'de vier v's': voorkomen, vergelden, voorlichten en vergoeden.

Redactie: De ACM bestrijkt als toezichthouder een heel breed terrein op verschillende niveaus. Passen jullie daarop jullie toezichtstrategie aan?

Martijn Snoep: Onze toezichtstrategie wordt meer bepaald door wat ons doel is, niet zozeer door het toezichtterrein of toezichtniveau waarop wij ons begeven. Je kunt bij het beschermen van het marktproces zowel voorlichten als voorkomen. Je kunt ook kiezen voor vergelden en vergoeden.

Datzelfde geldt bij het consumentenrecht. Daar hebben we wat zwaardere taken op het gebied van voorlichten omdat we consumenten willen voorlichten over wat hun rechten zijn. Tegelijkertijd lichten we ook bedrijven voor over de regels waaraan ze moeten voldoen. Ook in het consumentenrecht leggen we boetes op en ook in het consumentenrecht zijn we bezig met de vraag hoe consumenten gecompenseerd kunnen worden voor de schade die zij hebben geleden. Dus eigenlijk verschilt het instrumentarium en de toezichtstrategie niet zozeer per gebied of domein, maar hangt het meer af van de vraag wat we willen bereiken met een bepaalde interventie.

\section{Redactie: Hoe bepaal je die toezichtdoelen?}

Martijn Snoep: Dat doen wij o.a. in een strategisch bestuurlijk overleg. Dat bestaat uit het bestuur samen met de directeuren van de verschillende directies.

We kijken dan bijvoorbeeld of we wel voldoende zaken doen die boetewaardig zijn. Dat is van belang voor het afschrikwekkende karakter van ons handelen. In een ander geval kan sprake zijn van een nieuwe norm die nog niet is uitgekristalliseerd. Dan kiezen we eerst voor voorlichten, vervolgens een last onder dwangsom en pas daarna een boete. Zo bouwen we het op die manier op en kijken we iedere keer wat we precies willen bereiken ten aanzien van belangrijke thema's en wat de beste manier is om dat te doen.

Redactie: En wat is voor jullie op dit moment een belangrijk thema?

Martijn Snoep: Omdat we zo breed zijn, is het moeilijk om er één thema uit te halen. Twee heel belangrijke maatschappelijke thema's waar we nu mee bezig zijn, 
zijn, ten eerste, de digitale economie en de verandering in de economie als gevolg van digitalisering en, ten tweede, de energietransitie.

Dat zijn twee grote maatschappelijke ontwikkelingen waarbij wij kijken op welke manier wij daaraan een bijdrage kunnen leveren of een belemmering kunnen wegnemen. In ieder geval proberen wij ervoor te zorgen dat het vertrouwen van de burger in de werking van de digitale economie wordt versterkt en dat de energietransitie gaat slagen.

Dit zijn uiteraard niet de enige thema's waar wij mee bezig zijn. Er zijn ook grote maatschappelijke opgaven op het gebied van de zorg en zzp'ers, waarbij wij betrokken zijn. Wij kijken heel goed naar wat de behoefte is van de maatschappij. Uiteindelijk zijn wij daar dienend aan.

Redactie: Fe komt uit de advocatuur en kunt met een blik van buiten naar de ACM kijken. Wat heb je meegenomen uit joum vorige merk als advocaat in het mededingingsrecht en bestuursvoorzitter van De Braum Blackstone Westbroek?

Martijn Snoep: Ik denk dat de blik van buiten en de blik van een advocaat enorm kan helpen om in de organisatie duidelijk te maken dat een groot verschil bestaat tussen gelijk hebben en gelijk krijgen. Als advocaat ben je je hier veel bewuster van en kun je het gelijk hebben iets meer relativeren.

Een ander aspect is dat, voordat ik bij de ACM werkte, ik niet goed begreep waarom processen zo lang duurden.

$\mathrm{Nu}$ ik hier zit, begrijp ik dat beter. Er wordt zeer zorgvuldig gewerkt, zaken worden uitgebreid afgestemd, en gaan langs verschillende lagen van de organisatie. Ik denk nog steeds dat het sneller kan, maar ik begrijp het wel beter.

Redactie: De lange doorlooptijd is geen nieum probleem. Hoe proberen jullie dat probleem aan te pakken?

Martijn Snoep: Ik denk dat het helpt om van tevoren aan te geven hoeveel tijd je ergens aan wilt besteden en dat je daar ook heel hard in bent. Met een groot aantal projecten hebben wij dit gedaan door daar een 'tijdsklem' op te zetten. Dan geven we bijvoorbeeld aan dat we drie of zes maanden aan een onderzoek willen besteden en als er tegen die tijd geen overtreding is gevonden, dan houden we ermee op.

Dat is natuurlijk heel erg moeilijk, want je hebt wel zes maanden in een zaak geinvesteerd en als je nog een maand was doorgegaan, dan had je misschien net gevonden wat je zocht. Je moet daar echter onverbiddelijk in zijn en niet toch doorgaan. Dat hebben wij met elkaar besproken omdat er een opportunity cost is. Die extra maand die je aan een zaak besteedt, kun je niet ergens anders aan besteden. Dat is denk ik een besef wat nu sterker leeft en daardoor wordt er in de eerste zes maanden veel kritischer naar een zaak gekeken. Die zes maanden zijn gewoon een harde deadline geworden.

De praktijk is natuurlijk ingewikkelder en weerbarstiger dan hoe ik het hier nu uitleg, maar ik denk wel dat het tot gevolg heeft gehad dat een aantal dingen veel sneller zijn gegaan. Dat is leuk, want het geeft energie en vertrouwen om weer verder te gaan.

Redactie: Dan het volgende onderdeel van de estafettevragen: Als uit het toezicht overtredingen volgen, welk instrument kies je dan? Hoe maak je de keuze tussen handhaving of beinvloeding?

Martijn Snoep: Die keuze is wederom afhankelijk van het doel dat je precies wilt bereiken. Afhankelijk van de potentiële impact die je wilt maken, kan het zijn dat het doel tussentijds moet worden bijgesteld. Het kan ook zijn dat de inzet van instrumenten tussentijds verandert of dat überhaupt een ander instrument wordt gekozen.

Redactie: Zijn er ondermerpen maar je alleen maar klassieke handhavingsinstrumenten inzet, zoals bijvoorbeeld bij kartels?

Martijn Snoep: Nee, ook kartels komen in soorten en maten voor. Met bijvoorbeeld een duurzaamheidskartel (zoals de Kip van Morgen) ga je anders om dan met een klassiek kartel rond een aanbesteding waarin de aanbesteding wordt verdeeld in een achterkamer tussen lokale bouwondernemingen.

Redactie: Weten jullie inmiddels wat het beste merkt onder melke omstandigheden? Bijvoorbeeld dat je meet dat je bij een bepaald soort kartel op de ene manier moet handelen en bij een ander soort kartel op een andere manier?

Martijn Snoep: Nee, daarvoor hebben we te weinig zaken. Bij een organisatie als het UWV kun je goede statistische analyses maken over wat nu precies het beste werkt, maar in ons werk zijn er minder vergelijkbare waarnemingen en moeten we dus meer op onze intuïtie afgaan. We houden in de gaten of we als organisatie wel genoeg boetes opleggen binnen de verschillende domeinen. Het opleggen van boetes zorgt er toch voor dat je serieus wordt genomen en van boetes gaat een afschrikwekkende werking uit. Ik durf niet te zeggen dat we alle typen kartels hebben geclassificeerd en precies weten wat er bij elk soort kartel gedaan moet worden.

Redactie: Welke factoren megen jullie mee?

Martijn Snoep: We hebben een goed ontwikkelde, vrij specifieke matrix die als een soort leidraad werkt. Aan de hand van het gedrag kunnen we zien welke verschillende overwegingen wij, als ACM, moeten betrekken met het oog op de doelen voorkomen, vergoeden, vergelden en voorlichten. Op basis daarvan kunnen wij zien welk instrument bij welk type gedraging het beste past.

Redactie: Fe noemde al even dat je voldoende boetes moet opleggen om als toezichthouder serieus genomen te porden. Hoe nemen jullie dat mee in jullie afmegingen?

Martijn Snoep: Ook als de norm heel duidelijk is, hangt de hoogte van de boete sterk af van het soort bedrijf en wat de impact van het handelen of nalaten van dat bedrijf is. Als de norm enigszins vaag is dan moet je je wel achter de oren krabben of het boete-instrument het 
meest geëigende instrument is. Uiteraard zullen we nooit een boete opleggen om serieus genomen te worden. Maar we kunnen met dit doel wel specifiek op zoek gaan naar zaken die boetewaardig zijn.

Redactie: Heb je het idee dat de ACM in de afgelopen jaren minder serieus perd genomen en dat meer boetes opleggen nodig is?

Martijn Snoep: Er was en is nog behoorlijk veel kritiek op de ACM, met name in het mededingingsdomein. Dat is ook niet helemaal raar, want we hebben drie jaar geen boete opgelegd en dat is voor een mededingingsautoriteit best apart. Dus daar moeten we wat aan doen. Daarom heb ik ook gezegd dat die boetes er wel echt gaan komen, maar je moet niet een zaak die je anders op een andere manier zou hebben afgedaan nu opeens met een boete afdoen. Je moet de zaken zoeken waar je normaal gesproken een boete voor zou opleggen.

Redactie: We hadden het al even over die beïvloedingskant. Ondernemingen blijken niet altijd goed op de hoogte te zijn van de mededingingsregels. Hoe neem je dat mee in je toezicht?

Martijn Snoep: We hebben inderdaad onderzoek gedaan naar de vraag of bedrijven, met name mkb-bedrijven, de regels begrijpen. Daar was nog wel wat verbetering nodig en daar hebben we een vrij laagdrempelige campagne voor gevoerd, waarbij is ingegaan op wat er allemaal niet mag gelet op de mededingingsregels. De regels zijn eigenlijk niet zo complex maar ze zijn nog niet helemaal van nature ingesleten. Daarom maken we ze nog een keer duidelijk.

Redactie: Heb je het idee dat campagnevoeren in dit geval helpt, bereik je daar bedrijven mee?

Martijn Snoep: Ja, we zijn een maand geleden, op 1 oktober 2019, begonnen en het intensieve onderdeel loopt nu af. Je ziet dat de campagne wel dingen op gang brengt. De website wordt vaker bezocht, en de leidraden over verticale en horizontale samenwerking worden veel vaker gedownload. Het effect hebben we nog niet, maar dit gaan we meten. In ieder geval zie je dat het de aandacht aantrekt.

Het vergt herhaling, maar af en toe moet ook een boete worden opgelegd. Dan denkt men: ik moet toch even beter opletten. Het is uiteindelijk een combinatie van dingen. Ook hier geldt dat je op verschillende manieren je handhaving op orde kan brengen en voorlichting is daar gewoon een integraal onderdeel van. 